\title{
Humanização na Formação e no Trabalho em Saúde: uma Análise Documental
}

\author{
Medeiros, Lucilene Martorelli Ortiz Petin; Batista, Sylvia Helena \\ Universidade Federal de São Paulo- Campus Baixada Santista — lu21ortiz@gmail.com
}

INTRODUÇÃO:O Sistema Único de Saúde "é um dos maiores sistemas públicos de saúde do mundo...". Apresenta como princípios norteadores,a universalidade,a integralidade e a equidade da atenção à saúde.Alguns autores consideram o princípio da integralidade fundamental para se pensar a graduação em saúde.Souza JC,et al.(2008),fizeram uma reflexão sobre os desafios das instituições formadoras no sentido de realizarem uma "mudança de paradigma no ensino,[...] (para) tornar o aluno um sujeito mais ativo e crítico no seu processo de aprendizado,para que esse possa,enquanto profissional,mudar a realidade da assistência no Brasil".(p. 881).OBJETIVOS: Investigar as concepções de humanização presentes em artigos publicados no campo da formação em saúde no período de 2000 a 2012, e nos Projetos Político-Pedagógicos do campus da Universidade e de seus cursos.MÉTODOS:A metodologia abrangeu duas fases:revisão de literatura e análise documental.A revisão de literatura nos proporcionou uma familiaridade com os textos produzidos sobre a temática da humanização e seus autores,encontrados na base de dados SciElo,com os seguintes descritores: Humanização,Humanismo e Humanização na Formação.Na Análise Documental foram privilegiados os seguintes documentos PPP do Campus Universitário e dos cursos Psicologia, Nutrição,Terapia Ocupacional,Fisioterapia, Educação Física e Serviço Social.RESULTADOS:as concepções de humanização abrangem múltiplas facetas: apontam para a ética nos relacionamentos, garantia da comunicação com o outro, um conceito que orienta práticas,mas, também sobre a não preocupação com definições sobre o tema, e,sim,com o que a humanização produz.Apreendemos que a relação do profissional de saúde e os pacientes,são imprescindíveis para que a humanização esteja presente no atendimento em saúde. na fig. 1 apresentamos a inserção da expressão Humanização:por entre humanismo,formação humanística,prática humanizada/ humanística e Política Nacional de Humanização e na 2,apresentamos os resultados da expressão Humanização:por entre ética,cuidar/cuidado, integralidade,comunicação,relação com 0 paciente, relação pessoal/relacionamento interpessoal, nos PPPs.CONCLUSÕES:com referência ao processo de formação,os sentidos da humanização apontam a importância da relação professor-aluno como relevantes para a formação em saúde.No trabalho espera-se do profissional afetividade, sensibilidade,escuta qualificada para o acolhimento do usuário,pautando sua atuação em uma ética nas relações de trabalho.O termo humanização nos remete,também, a Atitude,a um modo de Entender,de Fazer,de Ser e Conviver com as pessoas.É como o profissional se implica com as questões de saúde e as formas de resolubilidade das demandas.

Medeiros, Lucilene Martorelli Ortiz Petin; Batista, Sylvia Helena. Humanização na Formação e no Trabalho em Saúde: uma Análise Documental. In: Anais do Congresso Internacional de Humanidades \& Humanização em Saúde [= Blucher Medical Proceedings, num.2, vol.1]. São Paulo: Editora Blucher, 2014. ISSN 2357-7282 DOI 10.5151/medpro-cihhs-10712 